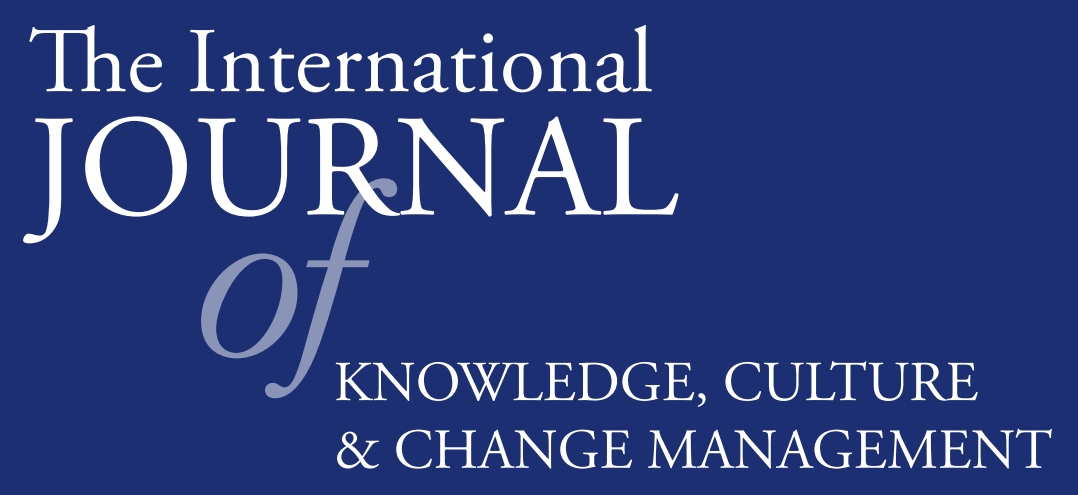

Volume 7, Number 10

The Influence of National and Organizational Culture on Absorptive Capacity of Chinese Companies

Feng Tian and Julian Lowe 
THE INTERNATIONAL JOURNAL OF KNOWLEDGE, CULTURE AND CHANGE MANAGEMENT http://www.Management-Journal.com

First published in 2008 in Melbourne, Australia by Common Ground Publishing Pty Ltd www.CommonGroundPublishing.com.

(C) 2008 (individual papers), the author(s)

(C) 2008 (selection and editorial matter) Common Ground

Authors are responsible for the accuracy of citations, quotations, diagrams, tables and maps.

All rights reserved. Apart from fair use for the purposes of study, research, criticism or review as permitted under the Copyright Act (Australia), no part of this work may be reproduced without written permission from the publisher. For permissions and other inquiries, please contact <cg-support@commongroundpublishing.com>.

ISSN: $1447-9524$

Publisher Site: http://www.Management-Journal.com

THE INTERNATIONAL JOURNAL OF KNOWLEDGE, CULTURE AND CHANGE MANAGEMENT is a peer refereed journal. Full papers submitted for publication are refereed by Associate Editors through anonymous referee processes.

Typeset in Common Ground Markup Language using CGCreator multichannel typesetting system http://www.CommonGroundSoftware.com. 


\title{
The Influence of National and Organizational Culture on Absorptive Capacity of Chinese Companies
}

\author{
Feng Tian, University of Ballarat, Victoria, Australia \\ Julian Lowe, University of Ballarat, Victoria, Australia
}

\begin{abstract}
The paper reports on a research study of knowledge acquisition by Chinese firms involved in collaborative ventures with foreign enterprises. The study uses 152 Chinese businesses and examines how absorptive capacity (ACAP), as conceptualized by Cohen and Leventahl (1990) and modified by Zahra and George (2002), and national and organizational culture differences, affect the transfer of knowledge between Chinese firms and their international partners. The study uses a multivariate modeling approach to examine the impact of a number of factors on successful knowledge transfer. It finds that ACAP has a significant effect on successful knowledge transfer but that the relationship is significantly modified by cultural differences and inter-firm communications. Culture per se does not influence knowledge transfer directly but does so through its impact on communications channels and institutions. Knowledge management practices and organization are also able to impact successful knowledge transfer.
\end{abstract}

Keywords: China, Absorptive Capacity, Culture Differences, Knowledge Management, Technology Transfer

\section{Introduction}

I

N THE WAKE of the extraordinary growth of the Chinese economy since the market reforms in the 1980s, there has been a growing body of research on possible causes of this growth. At the same time, scholars have also extended and developed theories and explanations of the management of knowledge in many different settings. However, as Holden (2001) observes 'the knowledge management literature is rather silent - though not completely silent - on knowledge management in its cross-cultural dimensions' (p. 155). This research focuses on that aspect in the context of technology and knowledge flows into China and is part of a wider study about the take - up of ideas and knowledge from outside of China into Chinese companies. The specific issues addressed are those dealing with the impact of culture differences, particularly national and organizational culture differences, on the transfer of knowledge and technology between a recipient Chinese firm and its international partner.

This research crosses a number of discipline boundaries; it involves the nature and management of foreign direct investment (FDI), the management of knowledge in 'learner' firms, and specifically the dynamic field of absorptive capacity (ACAP) developed from the seminal work of Cohen and Leventahl (1990). The contribution the paper makes is in its examination of the relative impact and interaction of absorptive capacity and culture differences in knowledge transfer in commercial projects.

The paper is structured as follows:
- Technology and knowledge acquisition is examined in a Chinese historical and cultural context.

- Anecdotal evidence on the cultural dimensions of technology transfer from published and unpublished cases is reviewed

- The role of cultural differences are examined in the context of a reconceptualised ACAP model and a number of hypotheses are proposed

- An empirical study is used to analyze whether culture differences influence the acquisition and transfer of knowledge by a sample of 150 Chinese firms from their foreign partners

The Chinese context introduces many factors that may influence knowledge transfer between donor and recipient. Following Hofstede (2005) differences between Chinese and Western cultures may represent an important hidden dimension impacting the efficiency and effectiveness of intra and inter - organizational communications. The speed of China's transformation may mean that whilst there are significant pools of knowledge, the overall innovation system is underdeveloped. The nature of China's acquisition of knowledge - through FDI rather than imitation and reverse engineering - as was the case in Japan's development (Freeman, 1987) may also affect indigenous capability to change and continuously improve.

These considerations influence the pertinent research questions. Is knowledge more difficult to transfer across different nations with dissimilar cul- 
tural contexts? Is culture a glue or a wall in technology transfer? And are national culture differences subordinate or superior to organizational culture differences? And finally what is the process of technology transfer between Chinese recipients and foreign donors and how is this affected by the nature of knowledge transferred and in particular the 'absorptive capacity' of Chinese firms?

\section{The Role of Knowledge Acquisition in the Historical and Current Chinese Context}

China's economy has grown at a compound average growth rate of 9.6 percent per annum since 1979 (OECD, 2005). This rate of growth is dramatic by any standards and is quite untypical of the transformation of developing economies. There are many explanations for this growth, but two in particular are relevant to this paper:

(i) The import of technology, knowledge and capital through joint ventures (JVs), and since 2000, foreign direct investment (FDI) in the form of wholly owned foreign enterprises (WOFE). Typically these inputs have occurred simultaneously. In 2005 \$US60bn was invested in China by international companies (USCBC, 2005). Technology and knowledge has been transferred from Western countries, usually as part of FDI, and has acted as a stimulus to the industrialization of the Chinese economy. China has absorbed vast quantities of knowledge and technology, increasingly through WFOEs. Table 1 illustrates the growth of FDI through WFOEs.

This has had an effect directly on recipient firms and indirectly on all firms via its impact on China's national innovation system (Liu and Buck, 2007). Chinese gross investment in $R \& D$ is now $\$ 17$ bn per year, and on a percentage of GDP basis it is the highest of all developing countries at $1.1 \%$. Published scientific papers have increased from 38,000 in 1998 to 111,000 in 2004. Patents applied - for, are now 476,000 in 2005 and China's high technology exports were $\$ 110$ bn per year in 2003, with China, in 2005, being the world's largest exporter of computers and electronics goods (OECD, 2005).

Table 1: Changing Vehicles for FDI in China (1979-2005)

\begin{tabular}{|l|l|l|l|l|l|l|l|l|l|l|l|l|}
\hline Year & $\begin{array}{l}1979- \\
89\end{array}$ & 1990 & 1991 & 1992 & 1993 & 1994 & 1995 & 1996 & 1997 & 1998 & 1999 & 2005 \\
\hline $\begin{array}{l}\text { Equity Joint } \\
\text { Ventures } \\
(\%)\end{array}$ & 38.7 & 41 & 50.8 & 50.1 & 49.5 & 48.6 & 43.5 & 43.5 & 40.6 & 33.2 & 32.3 & 24 \\
\hline $\begin{array}{l}\text { Contractual } \\
\text { Joint Ventures } \\
(\%)\end{array}$ & 41.9 & 19 & 17.8 & 22.8 & 22.9 & 24.6 & 19.5 & 19.5 & 23.7 & 22.4 & 16.5 & 3 \\
\hline $\begin{array}{l}\text { Wholly For- } \\
\text { eign-Owned } \\
\text { Enterprises } \\
(\%)\end{array}$ & 9.7 & 37.1 & 30.6 & 27.0 & 27.3 & 26.5 & 36.9 & 36.6 & 34.6 & 41.8 & 50.7 & 73 \\
\hline $\begin{array}{l}\text { Others } \\
(\%)\end{array}$ & 9.7 & 2.9 & 0.8 & 0.1 & 0.3 & 0.3 & 0.1 & 0.4 & 1.1 & 2.7 & 0.5 & 0 \\
\hline
\end{tabular}

(ii) The second factor in this growth is the ability and willingness of Chinese firms to absorb western technology and knowledge either through joint ventures or within WFOEs. Whilst national culture is sometimes seen as an inhibitor to knowledge transfer and commercial partnerships, it is possible that the Confucian philosophy that has dominated cultural values in China for 5000 years has played an important role in increasing the propensity of Chinese companies to acquire and absorb technology from their western partners. Confucius writes: "Exploring the old and deducing the new makes a teacher." 子 曰: 温故而知新, 可以为师矣 (Confucius, 1996).
Confucian philosophy emphasizes reflection and imitation in learning and Chinese national culture encourages the unity of the organization; the organization should grow together with individual performance downplayed. This is very different to the more individualistic cultures of western organisations and could support improved group rather than individual learning (Nonaka and Takeuchi, 1995; Zhao, 2005).

In spite of this growth China is a still a knowledge deficit country with exports of intellectual property being far less than imports (OECD, 2005). China has also grown through knowledge and capital acquisition in a way quite different from the parallel cases 
of Korea and Japan, where indigenous knowledge was used to reverse engineer western technologies, build a local innovation system and develop a highly competitive knowledge base (Freeman1987; Kim, 1997). Freeman notes that the reverse engineering that underpinned Japanese growth provided them with a total systems view of products and processes (p.43), and that they avoided FDI, at least until the late 1980s. This is in marked contrast to China, where FDI has played a major role. China has developed new technology concurrently with its focus on mature technology (Zedtwitz and Jin, 2004; Gao, 2003) and knowledge growth is increasingly contained within the organizational systems of the WFOEs as they try to insulate their companies from leakages into the overall innovation system.

Technology know-how, in the form of transfer of personnel, consultancy and equipment represented $78 \%$ of total technology royalties and fees for Chinese companies in 2005 (MOFCOM, 2006). This suggests two things, firstly, China is still the recipient for 'mature' technologies and secondly, the bulk of royalty payments are tied to knowledge that is less codified. This was certainly the case when Volkswagen set up a joint venture with SAIC in Shanghai in 1984, and although that relationship has changed markedly, patented technology is still a very minor part of technology flows into China.

\section{Absorptive Capacity in China and Inter-Organisational Knowledge Transfer}

A key aspect of this research is concerned with the absorptive capacity (ACAP) of Chinese firms. The concept was popularized by Cohen and Leventahl $(1989 ; 1990)$ in their seminal papers in the Economic Journal and the Administrative Science Quarterly. In a thematic analysis of the construct, Lane, Koka and Pathak (Lane, et. al, 2002) identify 189 citations in the mainstream management literature, as scholars used an ACAP framework to explain the variability in success of knowledge flows between organizations. The concept developed from two perspectives; (1) the recognition that $\mathrm{R} \& \mathrm{D}$ played an important role in economic growth (Solow, 1954) and (2) from organizational learning (OL), initially defined as the growing insights and successful restructuring of organizational problems (Simon, 1969) and the process of improving actions through better understanding (Foil and Lyles, 1985), so that problems can be tackled in a purposeful manner (Meyer, 1992). However the concepts of ACAP and OL are not the same, ACAP relies on learning to be most efficient where there is appropriate past experience - or a stock of expertise, whereas OL (Deeds, 2001) is more a process of reflective experience - and represents a flow concept. In particular, ACAP assumes that knowledge creation improve responsiveness to and acquisition of, external knowledge.

This paper uses ACAP to examine the successful performance of technology and knowledge transfer by foreign companies into Chinese organizations, and specifically to examine the impact of cultural factors, moderated by ACAP, structural antecedents and knowledge management systems on successful transfer performance. The research question guiding the study is:

'How do cultural antecedents affect the success of technology and knowledge transfer and how do Chinese firms manage the process of technology transfer and avoid the cultural differences?'

There are a number of definitions of ACAP and recently this has led to a reconceptualisation of the construct (Zahra and George, 2002; Todorova and Durisin 2007). In this research ACAP is defined by Cohen and Levinthal's original definition (1990) as

"The firms' capability to recognize the value to new knowledge, to assimilate it, and apply to commercial ends."

In this paper we examine the success of knowledge and technology transfer and the role that ACAP plays in that, particularly as it is influenced by cultural differences between technology donor and recipient or as Zhao (2005) puts it, between learner and teacher.

\section{Culture and Interorganisational Knowledge Transfer}

Culture is defined by Hofstede (2005) as the patterns of values, beliefs and assumptions learned in early childhood that distinguish one group of people from another. Therefore, national culture is strongly related to peoples' cognitive system, and might lead to different effects in peoples' learning process and response to the new knowledge. Inevitably culture is a socially constructed phenomenon and the dimensions of the construct which define it may vary significantly between observers. In particular, communications and culture are inextricably linked. This is particularly likely when knowledge is transferred across countries with dissimilar cultural contexts. Many management studies look at the national cultural differences as the major reason for failure or unsatisfactory transfer performance. This research suggests the problems may stem from communication barriers, inefficient cooperation, lack of commitment and conflicts caused by different values, beliefs and ways of doing things (Hofstede et al., 1990; Cartwright and Cooper, 1993; Pothukuchi, et al.2002). 

VOLUME 7

Steensma et al. (2002) investigated the influence of national culture on the formation of technology alliances between small and independent manufacturing firms from five countries. Their results suggest that national culture directly influences technology alliance formation and moderates the relationship between perceived technological uncertainty and formation. The study suggests that technology alliances are stronger between partners from societies that maintain cooperative values and avoid uncertainty. Newman and Noden (1996)'s study on the fit between management practice and national culture, which is based on Hofstede's five national culture dimensions and analogous management practices, found that work-unit performance is higher when management practices in the work-unit are congruent with the national culture. This study suggests that management practice should adapt to local national culture in order to achieve improved performance.

However, the popular belief in both the academic and the business fields, about the negative effect of national culture difference was not supported by Park and Ungson (1997)'s study on effects of partner nationality, organizational dissimilarity and economic motivation on the dissolution of joint ventures in a sample of 186 ventures. The study found out that cultural distance in general did not have an effect on dissolution; by contrast, cross-border joint ventures with partners from culturally distant countries (USJapanese joint ventures) lasted longer than US-US joint ventures. This study together with Bleeke and Ernst's(1993) case study results and with Barkema, et al.'s (1997) work support the proposition that prior relationships may provide a powerful counterbalance to cross-cultural differences through the creation of trust and familiarity, and these might reduce opportunistic behaviour and monitoring costs.

Whilst many scholars have assumed that national culture differences lead to stickiness (Szulanski, 1994) in knowledge transfer, there is increasing evidence that its effect is moderated by organizational culture, or that differences in culture can be complements, and can drive successful technology transfer (Holden , 2001).

\section{A Model of Knowledge Transfer}

Based on this discussion of the literature we propose a model of knowledge transfer that is deterministic with three groups of factors postulated to impact performance - defined as the success of the interorganizational knowledge transfers. The first category, following Teece (1979) and Cohen and Leventahl (1990) is absorptive fit. This proposes that:

- ACAP - defined by prior experience of the technology to be transferred and prior experience of collaborative relationships, and structural and cultural antecedents associated with the knowledge and technology will influence effective transfer (Teece, 1979; Zahra and George, 2001)

- Relational quality will reduce the transaction costs or friction in the relationship. We define relational quality in terms of culture fit (Hofstede and Hofstede, 2005); and effective communications (Holden, 2001)

- The management systems used to manage the knowledge flows and the skills and competences of individuals and their teams will improve effective transfer (Szuzlanski and Cappetta, 2003)

The expanded relationship examined in the study is then given in the following identity:

- Performance is defined as 'satisfaction with a successful transfer';

- Absorptive fit is defined as 'prior knowledge of the technology' and 'previous alliance experience', moderated by 'technology type' and 'technology age' and the form of 'collaborative venture';

- Relational quality is defined by 'national' and 'organizational culture fit', 'partner communications' and 'partner relationships';

- Management of knowledge is defined by the 'systems', 'company and partner skills' and 'knowledge management processes' used to manage knowledge transfer

The research model is illustrated in Figure 1 and proceeds on the basis of examining performance based on the antecedents of knowledge transfer and then assessing the impact of the collaborative relationship, culture fit and knowledge management systems on outcomes. 


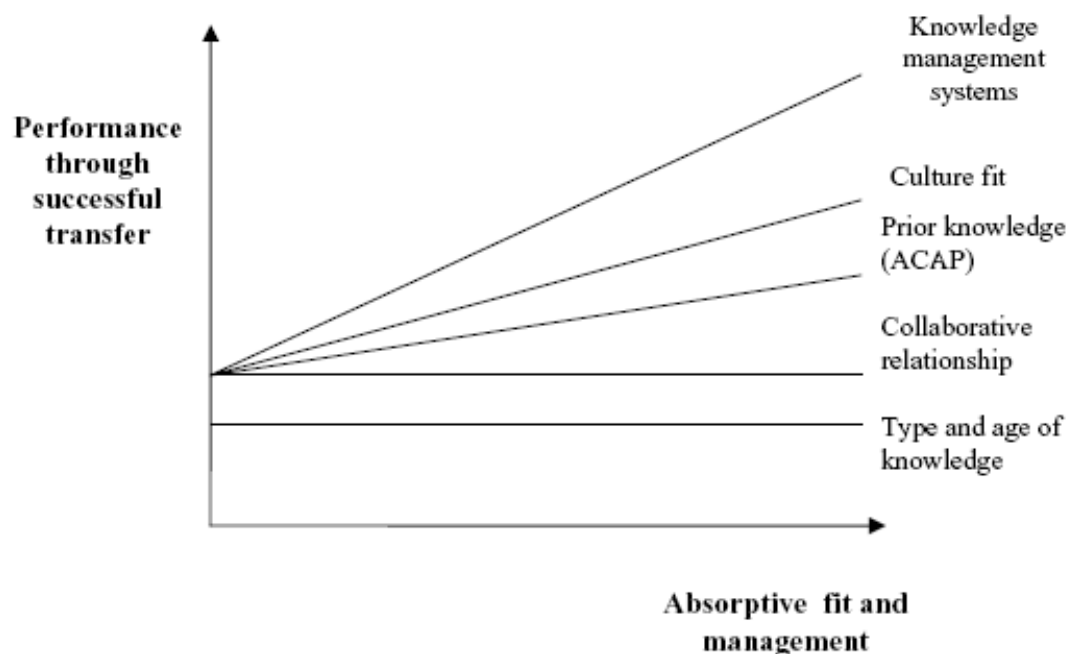

Figure 1: Determinants of Successful Knowledge Transfer

\section{The Study}

This research uses a group of 150 Chinese companies, who were recipients of technology and knowledge from overseas partners, to examine the impact of culture differences and ACAP on successful knowledge transfer.A mixed methodology was used and included:

- Scoping the attributes of ACAP from case studies and interviews

- Development of a survey measuring, at the level of the individual project, the dependent variable (satisfaction) and explanatory variables, listed below.

- 300 questionnaires were sent out and 152 were returned from WFOE, JV and other technology collaborations.

- The use of multivariate analysis to identify the determinants of technology transfer performance and the impact of culture and ACAP on this.

With the exception of technology type, the dependent and explanatory variables were measured on Likert scales in a questionnaire distributed to 300 middle managers in Joint Venture or WFOE organizations in Shenzhen and Shanghai. The questionnaire is available from the authors on request.

\section{Data Analysis and Discussion}

Model testing proceeded as follows and the results are shown in table 2 . The table contains four models which use performance measured by SATISFACTION as the dependent variable. In the first model the explanatory variables are a block of variables which include TECH AGE, TECH TYPE (the structural antecedents) and TECH EXPERIENCE, TECH RESOURCES, WORKING TIME, TECH KNOWLEDGE and ALLIANCE TYPE (the ACAP factors). In model two we add the blocks of factors that describe culture-CULTURE and COMMUNICATIONS, and a composite factor describing knowledge management systems in the recipient company. In model three and four MIS is added to the base model and the base model +culture model.

The base model yields an adjusted $\mathrm{R}^{2}$ of 0.287 and an $\mathrm{F}$ of 9.674 which is significant at $\mathrm{p}=0.000$. All of the ACAP factors are of the predicted sign with probabilities $\mathrm{p}=0.000$. The dummy variables on technology and alliance types are not significant. In the first augmented model, when communication and culture is added, the adjusted $\mathrm{R}^{2}$ increases to 0.345 and $\mathrm{F}$ is again significant at $\mathrm{p}=0.000$ with a value of 8.945. COMMUNICATION is significant at $\mathrm{p}=0.007$ but CULTURE is insignificant with a $\mathrm{p}=0.506$. MIS is then added to this base plus culture model and to the base model on its own. MIS improves on the base model with an increase in the adjusted $\mathrm{R}^{2}=0.294$, $\mathrm{F}=8.436$ with $\mathrm{p}=0.000$. The base model of ACAP and antecedent factors is therefore improved significantly by knowledge management factors (MIS) or cultural factors (CULTURE and COMMUNICATION), but not both together. 

VOLUME 7

Table 2: Determinants of Knowledge Transfer Performance

\begin{tabular}{|c|c|c|c|c|}
\hline Explanatory Variables & Model 1 & Model 2 & Model 3 & Model 4 \\
\hline & SC( Beta) & SC( Beta) & SC( Beta) & SC( Beta) \\
\hline Technology type & -0.01 & -0.05 & -0.06 & -0.03 \\
\hline Technology age & 0.02 & 0.04 & 0.03 & 0.01 \\
\hline Form of alliances & 0.04 & 0.01 & 0.05 & 0.07 \\
\hline Time working together & $0.35 * * * *$ & $0.24 * * *$ & $0.23 * * *$ & $0.32 * * * *$ \\
\hline Technology collaboration experience & $0.31 * * * *$ & $0.29 * * * *$ & $0.26^{* * *}$ & $0.27 * * *$ \\
\hline Our resources & $-0.29 * * * *$ & $-0.27 * * *$ & $-0.25 * * *$ & $-0.25 * * *$ \\
\hline Understanding of knowledge & $0.17 * * *$ & $0.15 * *$ & $0.17 * *$ & $0.18 * *$ \\
\hline Culture & & -0.05 & -0.07 & \\
\hline Communication & & $0.26^{* * *}$ & $0.25^{*}$ & \\
\hline Relationships & & 0.07 & 0.76 & \\
\hline MIS & & & 0.71 & $0.17 * *$ \\
\hline Adjusted R Squared & 0.287 & 0.345 & 0.337 & 0.294 \\
\hline $\mathrm{F}$ & 9.674 & 8.945 & 7.615 & 8.436 \\
\hline $\mathrm{N}$ & 151 & 151 & 143 & 143 \\
\hline $\mathrm{P}$ & $<0.000$ & $<0.000$ & $<0.000$ & $<0.000$ \\
\hline \multicolumn{5}{|l|}{$\begin{array}{l}\text { a } . \text { Dependent Variable: } \text { satisfaction } \\
\text { b. } \mathrm{SC}=\text { standardized coefficient } \\
\mathrm{F}=\mathrm{F} \text { statistic } \\
\mathrm{N}=\text { number of firms } \\
\mathrm{P}=\text { Probability } \\
* \text { significant at } \mathrm{p}<.1 \\
* * \text { significant at } \mathrm{p}<0.05 \\
* * * \text { significant at } \mathrm{p}<0.01 \\
* * * * \text { significant at } \mathrm{p}=0.000\end{array}$} \\
\hline
\end{tabular}

CULTURE and COMMUNICATION seem to be mutually correlated and we then examined whether CULTURE operates not directly on satisfaction but indirectly through COMMUNICATION. Using COMMUNICATION as the dependent variable we examine the impact of cultural factors on it and found that both CULTURE and LANGUAGE BARRIERS are strongly correlated with COMMUNICATION. A simple regression between the two explanatory variables and COMMUNICATION gives an adjusted $\mathrm{R}$ squared of 0.206 with the coefficient of LANGUAGE BARRIERS significant at $\mathrm{p}=0.1$ and coefficient of CULTURE is significant at $p=0.000$. The sign of both coefficients are positive.

Cultural factors are of considerable importance in technology transfer but their impact works through COMMUNICATION and RELATIONSHIPS rather than directly on technology transfer performance. Modeling this relationship requires path analysis but the results presented in this paper suggest this be an important area of future study. Similarly the structural antecedents of technology transfer (type and age of technology) and the form of collaborative relation- ships were not significant as determinants of performance, but in further preliminary analysis we believe they too act through communication effectiveness.

These results are significant in a number of ways. They confirm the work of Teece (1979) and Deeds (2001) that the structural antecedents can play an important role in facilitating technology transfer. The study also confirms empirically the Cohen and Leventahl (1990) proposition of the importance of absorptive capacity. They indicate that national culture differences on their own may not impact successful transfer but that through communication processes and enhanced knowledge management systems, they can have an impact.

\section{Conclusion}

As the pace of globalization increases we will see not just increasing cross border trade in goods and services but also in intellectual property through a variety of collaborative ventures. Two paradigms have dominated thinking in this area, one is the idea that the absorptive capacity of recipient firms will 
influence the passage of knowledge, and the other is that cultural differences can inhibit transfer and cause stickiness in knowledge movements. This research, through a study of 152 collaborative ventures in China involving international partners, finds that both paradigms can be supported but that this support is not straightforward. Good communications lies at the heart of successful transfer and successful transfer is dependent on this. However, good communications are themselves determined by a number of crosscultural factors. Without these factors knowledge might still be difficult to move around. What is also clear is that culture differences may be overridden by organizational differences or similarities if the partners have in place appropriate knowledge management mechanisms.

\section{References}

Barkema, H.G., Shenkar, O., Vermeulen, F., Bell, J.H.J. (1997), "Working abroad, working with others: how firms learn to operate international joint ventures", Academy of Management Journal, Vol. 40 No.2, pp.426-42.

Bleeke, J., Ernst, D. (1993), “Manager's choice”, in Bleeke, J. , Ernst, D. (Eds), Collaborating to Compete: Using Strategic Alliances and Acquisitions in the Global Marketplace, McKinsey \& Company, New York, NY, pp.11-16.

Cartwright, S., Cooper, L.C. (1993), "The role of culture compatibility in successful organization", The Academy of Management Executive, Vol. 34, pp.67-80.

Cohen, W., M. and D. Levinthal, A. (1989), "Innovation and learning: The two faces of R\&D”, The Economic Journal, Vol. 99: p. 569-596.

Cohen, W., M. and D. Levinthal, A.(1990), “Absorptive Capacity: A New Perspective on Learning and Innovation”, Administrative Science Quarterly, Vol. 35: pp. 128-152.

Confucius, (1996), The Analects. Hertfordshire: Wordsworth Editions Limited.

Deeds, D.L. (2001), "The role of R\&D intensity, technical development and absorptive capacity in creating entrepreneurial wealth in high technology start-ups", Journal of Engineering and Technology Management, Vol. 18(1): pp. 2947.

Freeman, C. (1987). Technology policy and economic performance: Lessons from Japan. London: Pinter Publishers.

Foil, C.M. and Lyles, M. (1985) "Organizational Learning”, Academy of Management Review, Vol. 10(4): pp. 803-813.

Gao, X., (2003), “ Technological capability catching up: follow the normal way or deviate", Massachusetts Institute of Technology Sloan School of Management: PhD Thesis.

Hofstede, G., Neuijen, B., Ohayv, D.D., Sanders, G. (1990), "Measuring organisational cultures: a qualitative and quantitative study across twenty cases", Administrative Science Quarterly, Vol. 35 pp.286-316.

Hofstede, G., \& Hofstede, G. J. (2005). Cultures and Organizations: Software of the Mind. New York: McGraw-Hill.

Holden, N. (2001). "Knowledge management: raising the spectre of the cross-cultural dimension", Knowledge and Process Management, Vol. 8(3): pp.155-163.

Kim, L. (1997), Imitation to Innovation: The Dynamics of Korea's Technological Learning, Boston: Harvard Business School Press.

Lane, P.J., B. Koka, and S. Pathak, (2002), "A thematic analysis and critical assessment of absorptive capacity research", Academy of Management Proceedings, p. M1.

Liu, X. and Buck, T. (2007), "Innovation performance and channels for international technology spillovers: Evidence from Chinese high-tech industries", Research Policy, Vol. 36(3): pp. 355-366.

Meyer, J.W., (1992), "Conclusion: Institutionalization and the Rationality of Formal Organizational structure", in J.W.S. Meyer, W.R., (Edit), Organizational Environments. Ritual and Rationality, New Delhi: Newbury Park, London. pp. 261-282.

MOFCOM., (2006), The Technology Import Report 2005, retrieved 03/04, 2006, from http://kjs.mofcom.gov.cn/aarticle/ztxx/dwmyxs/u/200601/20060101418975.html

Nonaka, I. and Takeuchi, H., (1995), The knowledge-creating company: how Japanese companies create the dynamics of innovation. New York: Oxford University Press.USCBC,(2005), F.D.I. in China

OECD, (2000), Main determinants and impacts of foreign Direct Investment on China 's economy. retrieved 03/04, 2006, from http://www.oecd.org/dataoecd/57/23/1922648.pdf

OECD, (2005), G.D.P. Index and Percentage Changes. retrieved 03/04, 2006, from http://www.oecd.org/dataoecd/30/12/29859992.xls

Park, S.H., Ungson, G.R. (1997), "The effect of national culture, organisational complementary, and economic motivation on joint venture dissolution", Academy of Management Journal, Vol. 40 No.2, pp.279-307.

Pothukuchi, V., Damanpour, F., Choi, J., Chen, C.C., Ho Park, S. (2002), "National and organizational culture differences and international joint venture performance", Journal of International Business Studies, Vol. 33 No.2, pp.243-65.

Solow, R., (1954), "The survival of mathematical economics", Review of Economics and Statistics, Vol. 36(4): p. $372-374$. Simon, H.A., (1969), The Sciences of the Artificial. 1st ed. MIT Press.

Steensma, H., et al., (2000), "The influence of national culture on the formation of technology alliances by entrepreneurial firms", Academy of Management Journal, Vol. 43(5): pp. 951-973.

Szulanski, G. (2003). Sticky knowledge: Barriers to knowing in the firm. London: SAGE publications.

Szulanski, G., \& Cappetta, R. (2003). Stickiness: Conceptualizing, Measuring and Predicting difficulties in the transfer of knowledge within organizations. In M. Easterby-Smith \& M. Lyles (Eds.), Blackwell Handbook of Organizational Learning and Knowledge Management (pp. 513-534). Oxford, U.K: Blackwell. 
Todorova, G. and Durisin, B. (2007), “ Absorptive capacity: valuing reconceptualization “, Academy of Management Review, Vol. 32(3): pp. 774-786.

Zahra, S.A. and George, G. (2002), “Absorptive capacity: A review, Reconceptualization, and extension”, Academy of Management Review, Vol. 27(2): pp. 185-203.

Zhao, Z., (2005), “A Dual Networks Perspective on Inter-Organizational Transfer of R\&D Capabilities: International Joint Ventures in the Chinese Automotive Industry “, Journal of Management Studies, Vol. 42(1): pp. 127-160.

Zedtwitz, M.V. and Jin, J. (2004), "Process of Technological Capability Development in the Mobile Telephone Manufacturing Sector: A Case of Eastcom (China) “ in Proceedings of the 13th IAMOT Conference. Washington, DC, USA.

\section{About the Authors}

\section{Feng Tian}

Tian comes from Shenyang, a Manchu historical city of north-eastern China, with a population of 8 million. Tian has worked in a senior executive position in a number of Chinese companies. She was awarded a Bachelor of International Marketing and Business (Honours) degree from North Eastern University in China in 1993, Graduate Diploma in Business and Management from Prime College in Malaysia in 2003, and Master of Business Administration degree with a stream in Research from University of Ballarat in December 2004. Her MBA dissertation focused on the impact of globalisation on the Chinese TV manufacturing industry. This was published in the prestigious China Social Academy Management Journal. Tian is now completing her doctorate, her research interests are in knowledge management, absorptive capacity, knowledge stickiness, technology transfer in Chinese firms.

\section{Julian Lowe}

Professor Julian Lowe is Professor and Director of the Centre for Regional Innovation and Competitiveness (CRIC), university of Ballarat, Australia and Professor of Strategic Management at University of West England (Bristol),UK. Professor Lowe was privous Professor of Business Policy at University of Wollongong and Senior Lecturer at the University of Nottingham and Bath. Professor Lowe has published widely in the area of Strategy, entrepreneurship collaboration, alliances and technology licensing. Recent work includes a study of technology licensing in UK manufacturing, managing alliance in the aerospace industry; clustering and regional development; Chinese economics and management and fast growth new firms. 


\section{THE INTERNATIONAL JOURNAL OF KNOWLEDGE, CULTURE AND CHANGE MANAGEMENT}

\section{EDITORS}

Mary Kalantzis, University of Illinois, Urbana-Champaign, USA.

Bill Cope, University of Illinois, Urbana-Champaign, USA.

\section{EDITORIAL ADVISORY BOARD}

Verna Allee, Verna Allee Associates, California, USA.

Zainal Ariffin, Universiti Sains Malaysia, Penang, Malaysia.

Robert Brooks, Monash University, Melbourne, Australia.

Bruce Cronin, University of Greenwich, UK.

Rod Dilnutt, William Bethway and Associates, Melbourne, Australia.

Judith Ellis, Enterprise Knowledge, Melbourne, Australia.

Andrea Fried, Chemnitz University of Technology, Germany.

David Gurteen, Gurteen Knowledge, UK.

David Hakken, University of Indiana, Bloomington, Indiana, USA.

Sabine Hoffmann, Macquarie University, Australia.

Stavros Ioannides, Pantion University, Athens, Greece.

Margaret Jackson, RMIT University, Melbourne, Australia.

Paul James, RMIT University, Melbourne, Australia.

Leslie Johnson, University of Greenwich, UK.

Eleni Karantzola, University of the Aegean, Rhodes, Greece.

Gerasimos Kouzelis, University of Athens, Greece.

Krishan Kumar, University of Virginia, USA.

Martyn Laycock, University of Greenwich and managingtransitions.net, UK.

David Lyon, Queens University, Ontario, Canada.

Bill Martin, RMIT University, Melbourne, Australia.

Pumela Msweli-Mbanga, University of Kwazulu-Natal, South Africa.

Claudia Schmitz, Cenandu Learning Agency, Germany.

Kirpal Singh, Singapore Management University, Singapore.

Dave Snowden, Cynefin Centre for Organisational Complexity, UK.

Chryssi Vitsilakis-Soroniatis, University of the Aegean, Rhodes, Greece.

Please visit the Journal website at http://www.Management-Journal.com for further information:

- ABOUT the Journal including Scope and Concerns, Editors, Advisory Board, Associate Editors and Journal Profile

- FOR AUTHORS including Publishing Policy, Submission Guidelines, Peer Review Process and Publishing Agreement

\section{SUBSCRIPTIONS}

The Journal offers individual and institutional subscriptions. For further information please visit http://ijm.cgpublisher.com/subscriptions.html. Inquiries can be directed to subscriptions@.commongroundpublishing.com 